\title{
E-cigarettes and youth: a major Public Health concern
}

\author{
Fabrizio Virgili ${ }^{1}$, Raffaella Nenna ${ }^{2}$, Shira Ben David ${ }^{1}$, Enrica Mancino ${ }^{3}$, Greta Di Mattia ${ }^{3}$, \\ Luigi Matera ${ }^{3}$, Laura Petrarca ${ }^{2}$, and Fabio Midulla ${ }^{1}$ \\ ${ }^{1}$ Sapienza University of Rome \\ "Sapienza" University of Rome \\ ${ }^{3}$ University of Rome
}

July 2, 2021

\begin{abstract}
The use of electronic cigarettes (e-cigarette) and vaping devices started as a potential aid for cessation and reducing the harmful consequences of cigarette smoking, mainly in the adult population. Today e-cigarette use is highly increasing in vulnerable populations, especially young and pregnant women, due to the misconception of its harmless use. Despite the growing acknowledgment in e-cigarette as a potential harmful device, and due to mixed information found concerning its beneficial aid for smokers, along with an insufficient clinical study done in human models, it is important to further evaluate the possible benefits and risks of non-combusting, vaping nicotine or non-nicotine delivery devices. In this review we tried to summarize the latest updated information found in the literature, concentrating mainly in the variety of adverse effects of e-cigarette use and its contribution for recent and future health concerns.
\end{abstract}

\section{Introduction}

Tobacco smoke undoubtedly remains world's leading cause of preventable disease ${ }^{1}$. Over the last decade, reducing cigarette consumption has become a Public Health goal, therefore prevention campaigns intensified and restrictions on their marketing and access escalated ${ }^{2}$.

Electronic cigarettes (also known as E-cigs, Electronic Nicotine Delivery Systems-ENDS, vaping device or e-vaporizers) are an electronic device that can vary in size and shape, consisting of a battery, an electrical heater and a liquid, which is aerosolized to be inhaled. Liquid composition can include nicotine, a solvent and an utmost variety of flavorants ${ }^{3}$. Taking shape as a smoking cessation strategy or - in actual fact - as a legal alternative where conventional smoking was prohibited, e-cigarettes, invented by Hon Lik (a Chinese pharmacist), were patented in 2003. However, only in 2007 they became commercially available in USA and Europe $^{4}$.

In contrast with a consistent decline in smoking prevalence among youth ${ }^{5}$, over the past few years electronic cigarettes have rapidly gained popularity to the point of becoming the most common tobacco product in this age group ${ }^{6}$. Their social acceptance, together with their widespread availability, contributed to drastically increase primary use by adolescents and second-hand exposure in children, outlining the need for an assessment of their health effects in these categories ${ }^{7}$.

In 2018, the National Youth Tobacco Survey reported that 20.8\% of high school students and $4.9 \%$ of middle school students currently used e-cigarettes ${ }^{8}$. Since the introduction of pod-based devices, vaping prevalence has tremendously increased, reaching $28 \%$ in $2019^{9}$ and even $40.5 \%$ among 12 th graders ${ }^{10}$. In Great Britain, during $202016.4 \%$ of 11-18-year-old students had tried (at least once) e-cigs, compared to $15.4 \%$ in 2019 and to $12.7 \%$ in 2015. Also current use increased since 2015 from $2.4 \%$ to $4.8 \%^{11}$. Prevalence of current e-cigarette smokers in Italy doubled from 2014 (8\%) to 2018 (18\%), whereas the number of ever smokers has 
risen by $60 \%$ (from $28 \%$ to $44 \%)^{12}$. According to forecasts, e-cigarettes sales will surpass those of traditional tobacco by $2023^{13}$.

Marketing has certainly played a major role in vaping prevalence inflection among children and adolescents. E-cigarettes can be purchased in vape shops, tobacco vendors, gas stations, groceries, pharmacies and even online $^{14}$. The manufacturing companies, often owned by tobacco firms, address their products to youth by promoting appealing flavours and using multiple communication channels: television advertisings; targeted advertisements at the point of sale; web sites and social media; celebrity partnerships; free samples at youthoriented events $^{15-17}$. In 2016, $78.2 \%$ of middle and high school students have been exposed to e-cigarette advertisements from at least 1 source and increasing exposure seemed associated with higher odds of use $\mathrm{e}^{17}$. Social media are easily accessible by teenagers and convey the use of e-cigarettes as socially acceptable ${ }^{18}$; despite ENDS being born as a smoking cessation strategy, less than $1 \%$ of twitter posts concerning vaping are related to smoke cessation ${ }^{19}$. Apparently, only $8 \%$ of adolescents take up e-smoking as a nicotine replacement strategy ${ }^{20}$ whereas the most common reasons underlying vaping experimentation in pediatric population are: curiosity, social influence, availability at low cost, enjoyable flavors, ease of concealment ${ }^{21-23}$. Sustained use is then encouraged by misperceptions about safety, nicotine content and social prevalence ${ }^{21,24-26}$.

A cross-sectional analysis pointed out that positive expectancies regarding e-cigarette use (e.g. gaining respect of peers and chances of being liked by partners, reducing stress, enjoying throat sensation) are related with a greater prevalence of current $u^{2} \mathrm{e}^{27}$. Users exhibit the lowest perceptions of harm and more positive attitudes towards e-cigarettes when compared with non-users ${ }^{28}$. Adolescents perceptions - which affect their decision-making process - are generally biased in the direction of their own experience, a phenomenon referred to as "false consensus effect" ${ }^{29}$ : for instance, teens tend to overestimate actual smoking rate among peers $^{30}$, therefore they may be more prone to develop such addiction. In this regard, Gorukanti et al. ${ }^{28}$ administered $9^{\text {th }}$ and $12^{\text {th }}$ graders from California an online survey to investigate their attitudes towards e-cigarettes and whether they differ by past use. Findings showed that prevalence of both e-cigarette and cigarette use among parents, siblings, and close friends was higher in adolescents who have ever used an ecigarette. At the same time, vapers believed more peers and relatives smoke e-cigarettes than do non-users. A variable - but worrying - percentage of participants agreed that smoke from e-cigs was water, that they do not contain tobacco or tar and that vaping felt cleaner and safer than smoking. Ever cigs or e-cigs users were more likely to agree about. Nonusers, instead, were more prone to consider e-cigarette vapor harmful to children. Participants were more open to e-cigs use both indoor and outdoor, compared to traditional cigarettes.

\section{Technical specifications and device evolvement}

E-cigarettes different models share a basic operating mode. The mouthpiece allows the vaper to draw air, whose flow activates a sensor, causing the heating of a filament inside the atomizer. A capillary action brings the liquid to the filament. The warmed filament vaporizes the fluid; then, the condensation of the produced gas with atmospheric water generates an inhalable aerosol. Products lacking the air-flow sensor are provided with a button whose pressure closes a circuit that activates the battery ${ }^{31}$.

Throughout the years, e-cigarettes design and technical features evolved, providing the market with updated products meeting consumers' different demands. First generation ECs, usually referred to as cig-a-likes, have been conceived to resemble the design and feeling of traditional cigarettes. They are equipped with low voltage batteries, available in different versions: the 3-piece style, composed of independent atomizing unit, battery, and fluid reservoir; the 2-piece style, with the battery being the only separable element; the 1-piece disposable, to be discarded after one use. Since the fragile atomizers can be easily damaged, variations in performance aren't unlikely ${ }^{32,33}$. In second generation ECs, known as "clearomizers", larger batteries of variable voltage are provided with a removable atomizing unit enclosed in a shell which is screwed into the fluid reservoir and the battery. Their larger fluid reservoirs are fillable ${ }^{34-36}$. Using a third generation EC ("mods"), in which the reservoirs disassemble, the consumer can regulate battery voltage and power. The atomizing units exists in three versions (various styled, replaceable dripping, sub-ohm). Despite some metal components being absent, the overall amount of metal is greater. The concurrent increase in battery 
power makes third generation products able to release higher concentrations of metals into the aerosol. Furthermore, the presence of two filaments in some atomizers enhances heat distribution, resulting in a more abundant production of aerosol ${ }^{37}$. For the replaceable dripping atomizers, vapers build their own coils and drip the fluid directly onto them; otherwise a fluid thank encases the atomizer ${ }^{37,38}$.

E-cigarettes modernisation process helped contain health implications. In early models, tin solder joints tied the filament to a thicker wire. These joints could be friable, eventually releasing tin in aerosols, a flaw remedied by coating the thick wire with silver, using stable tin solder joints outside of the atomizer, or joining wires by clamping or brazing rather than soldering. The thick wire, made of nickel or copper coated with either tin (associated with stannosis and pneumoconiosis ${ }^{39}$ ) or silver, was not included in second generation products and later ${ }^{40}$. By removing the silicon sheath from second and third generation products, its presence in aerosols drastically decreased ${ }^{41}$. Nonetheless, the empowerment in $2^{\text {nd }}$ and $3^{\text {rd }}$ generation batteries, accompanied by the increase in atomizer size and mass of metal, allowed to generate larger amounts of aerosol ${ }^{37}$, resulting at the same time in a greater transfer of particles, metals, toxicants ${ }^{35,36}$. Furthermore, as voltage/power ratio increased, new potentially toxic by-products could emerge from the liquid ${ }^{41}$. Likewise, in larger reservoirs such as those of second and third generation ECs, fluid stagnation could enrich aerosols with additional toxicants through repeated use $^{36}$.

Fourth generation ECs, referred to as pod mod devices and equipped with fix voltage batteries, have become popular among teenagers as a socially acceptable alternative to conventional cigarettes due to their stylish design (e.g. USB or teardrop shape), wide selection of flavours and user-friendly functions ${ }^{42,43}$. Their likeness to an USB memory stick allows them to be discretely used in no smoking areas and easily concealed from parents, contributing to a new widespread phenomenon, known as "stealth vaping" ${ }^{19,44,45}$. A distinctive feature of fourth generations devices is the use of nicotine in its protonated form, which reduces the irritating effect on throat mucosa while increasing the amount of nicotine delivered in aerosols ${ }^{46}$.

The heterogeneity outlined above complicates research on potential health effects, since the variability in design and technical features prevents us from discussing e-cigarettes as a single device. For instance, power output affects yield and aerosols content: in order to resemble cigarettes, closed systems are provided with lower-voltage batteries and/or higher resistance heating elements ${ }^{47}$, whose thermal breakdown can produce toxicants normally absent in traditional cigarettes ${ }^{48}$. Devices allowing the user to drip liquid onto the heating element can generate an amount of aldehyde equal or higher than tobacco cigarettes, due to the high temperatures reached ${ }^{49}$. Furthermore, besides type and age of the device, e-cigarette health impact depends on multiple variables including ambient factors (e.g. climate conditions, room size and density of people) and user's habits (puff length and frequency) ${ }^{50}$.

\section{Content}

Aerosol composition is affected even by the solvent employed, being vegetable glycerin (VG), propylene glycol (PG) and their mixture the most widely used. They can also influence particle-size distribution, therefore the region of deposition in the respiratory system ${ }^{51}$. A higher percentage of propylene glycol seems enhancing flavour and strengthening the so-called "throat hit", whereas a higher percentage of vegetable glycerine may increase vapor production ${ }^{52}$. Vegetable glycerine exposure has been associated with irritation of eyes, lungs, and oesophagus mucosa ${ }^{53}$. Likewise, its higher boiling point requires the heating element to reach higher temperatures, resulting in a greater risk of toxicants emission ${ }^{49}$. The highest yield of aldehydes occurs in devices containing propylene glycol ${ }^{54}$, also related to upper respiratory infection-like symptoms ${ }^{55}$. It has been documented that a PG/VG mixture produces more ROS than each component alone ${ }^{56}$.

A vast amount of studies aimed at characterizing e-cigarettes emissions and variously reported measurable amounts of ethanol, volatile organic compounds (VOCs), polycyclic aromatic hydrocarbons (PAHs), silicon, lead, nickel, air pollutant, formaldehyde, acetaldehyde, isoprene, acetic acid, 2-butanodione, acetone, and propanol $^{56-58}$. Volatile organic compounds can provoke eye and respiratory tract irritation, neurological impairment and liver damage ${ }^{59}$. Polycyclic aromatic hydrocarbons demonstrated carcinogenic, respiratory, immunological, neurological and reproductive effects ${ }^{60}$. Reactive carbonyls such as aldehydes and acrolein 
(product of glycerol constituents vaporization ${ }^{61}$ ) elicit airway constriction, direct damage to airway epithelium and alterations in gene expression, in addition to neutrophils activation, degranulation and apoptosis ${ }^{62}$.

The extraordinarily wide variety of flavorants available amplifies the heterogeneity in E-cigs aerosol composition. These chemical components are generally employed in food industry and recognized as safe additives but this does not imply their harmlessness when inhaled ${ }^{63}$. Some are known allergens (e.g. cinnamaldehyde for cinnamon aroma) ${ }^{64}$, others may provoke ocular and airway irritation (e.g. benzaldehyde for fruity aromas $)^{65}$. Pre-clinical studies demonstrated that flavoring chemicals elicit pro-inflammatory responses in lung epithelial cells and fibroblasts and decrease transepithelial resistance in bronchial epithelial cells ${ }^{66}$. Likewise, diacetyl and acetyl propionyl (butter flavoring volatiles) seem to underlie bronchiolitis obliterans, as seen in microwave pop-corn producing factory workers ${ }^{67,68}$. Besides, flavored e-cigarettes are misleadingly considered less harmful than those with tobacco flavor, therefore used carelessly by youth ${ }^{69}$.

An additional concern is represented by the inconsistencies between declared nicotine levels and actual nicotine content, which have been detected even in liquids supplied from the same company ${ }^{70}$.

Moreover, e-cigs nicotine derives from tobacco plant, thus e-liquid can include other tobacco-related toxicants, such as tobacco-specific nitrosamines $\left(\right.$ TSNAs$^{71}$.

\section{Vaping health implications}

An uncountable amount of studies aimed at evaluating e-cigarette potential consequences on human health and the most updated panorama of scientific literature provides increasing evidence of vaping harmfulness. According to the centre for disease control and prevention $(\mathrm{CDC})^{72}$, although e-cigarettes harmful effects are fewer in comparison to burned cigarettes, they are considered unsafe, harmful for brain development and increase the risk to future addictions especially in kids, adolescence and young adults.

\section{Respiratory effects}

Among e-cigarettes adverse health effects, respiratory impact is by far the most extensively studied. In the same way as conventional cigarettes smokers, vapers' pulmonary epithelium is typically damaged ${ }^{73}$ and bronchial mucosa chronically inflamed ${ }^{74}$. Proteomics of e-cigarette users' sputum document higher levels of myeloperoxidase, neutrophil elastase and proteinase-3, indicative of neutrophil activation. Furthermore, chronic vapers' neutrophils display a greater propensity for NET formation when compared to cigarette smokers or non-smokers ${ }^{62}$. Bronchial inflammation result in a higher respiratory impedance and flow resistance ${ }^{75}$ (evidenced by a lower $\mathrm{FEV}_{1}$ and $\mathrm{FEV}_{1} / \mathrm{FVC}^{76}$ ) as well as a significant decrease in fractional exhaled Nitrogen Oxide ${ }^{77}$, both observed in e-cig users.

From a clinical perspective, these pathophysiological alterations could underlie the considerable increase in asthma and bronchitic symptoms reported by e-cigarettes users, especially adolescents. According to various studies involving high school students, vapers have a twofold higher risk of chronic cough, phlegm or dyspnea, together with a greater incidence of asthma ${ }^{78,79}$. A higher prevalence of e-cigarette use is reported among adults living with a child affected by asthma ${ }^{80}$, whose risk of acute exacerbation can increase by $30 \%^{81}$. Schoolwork is indirectly affected too, as a result of absenteeism secondary to the aforementioned symptoms ${ }^{82}$. Preclinical studies ${ }^{83}$ suggest also a detrimental effect on mucociliary clearance which, coupled with a decreased cough sensitivity ${ }^{84}$ and the overexpression of PAF-R (pneumococci's receptor ${ }^{85}$ ), predispose vapers to increased rates of pneumonia ${ }^{86}$.

In parallel to the increasingly wide distribution of e-cigarette, a growing number of cases helped characterize a new nosological entity, which is now referred to as E-cigarette or Vaping Associated Lung Injury (EVALI). It is a diagnosis of exclusion that requires use of e-cigarettes and related products 90 days prior to symptom onset in addition to pulmonary infiltrates on imaging ${ }^{87}$. The prevalence seems higher in youth: indeed, the median age of the initially reported cases was $19^{88}$. The hypothesized causative agent of lung injury is vitamin $\mathrm{E}$ acetate, which may be found in cartridges of THC flavored e-cigarettes, widespread among high school students ${ }^{89}$. Its aerosolization generates ketene, that is irritant to airways and disrupts phospholipid bilayer decreasing surfactant effectiveness ${ }^{90}$. EVALI can occur with shortness of breath, cough, tachycardia, 
tachypnea, pleuritic pain and rarely hemoptysis. Nausea and abdominal pain, as well as fevers and chills are not infrequent. Up to $30 \%$ of the affected require mechanical ventilation and up to $70 \%$ the admission to intensive care units ${ }^{90-92}$. Bilateral lower-lobe predominant ground glass and consolidative opacities with subpleural sparing are the most typical findings at chest imaging. Other possible radiographic patterns include dense consolidative opacities (as in Acute Respiratory Distress Syndrome), diffuse patchy and confluent consolidative opacities (as in Cryptogenic Organizing Pneumonia) or upperlobe ground glass opacities with air trapping (as in hypersensitivity pneumonitis) ${ }^{92,93}$. After ruling out other respiratory infections (viral panel, urine antigen testing, sputum and blood cultures), a bronchoscopy with Bronchoalveolar Lavage and, if possible, transbronchial biopsies, should be performed unless clinical severity precludes it ${ }^{90,94}$. Steroids should be started concomitantly with antibiotics, especially in patients with respiratory failure; in less severe presentations they can be delayed after infectious causes are ruled out. Response to methylprednisolone is generally excellent ${ }^{91}$. Based on the severity of the clinical picture, patients can benefit from high-flow oxygen therapy, noninvasive ventilation or require mechanical ventilation ${ }^{88,91,95}$.

Case reports point out an association between e-cigarette smoking and lipoid pneumonia, acute eosinophilic pneumonia, subacute bronchial toxicity and even reversible cerebral vasoconstriction syndrome ${ }^{96-99}$.

Second- and thirdhand exposure

Concerning e-cigarettes impact on pediatric population, an often-underestimated aspect is second- and thirdhand smoke. Approximately $20 \%$ of parents using e-cigarettes follow strictly enforced vape-free home and car policies; among dual users, $64 \%$ has a smoke-free and only $26 \%$ a vape-free home policy, which implies a general misperception about e-cigarettes safety. Furthermore, younger parents are more likely to lack a home and car policy ${ }^{100}$. There is evidence that nicotine metabolites in serum, as well as saliva and urine cotinine levels, are superimposable among non-using adults secondhandedly exposed to e-cigarettes and conventional cigarettes $^{101}$. Even secondhand particular matter exposure levels can equal that of traditional smoking ${ }^{102}$ and appear to be greater in nicotine-free devices ${ }^{103}$.

Vaping during pregnancy (fetal developmental effects)

Of no less importance is fetal exposure to nicotine during pregnancy. Vaping prevalence in pregnant women has been estimated to stand between $0.6 \%$ and $15 \% 104$. Nicotine can cross the placenta and measurable nicotine levels can been detected in offspring of mothers smoking during pregnancy ${ }^{105}$. In uterus nicotine exposure increases the risk for eclampsia, premature birth, cleft lip and palate, reduced birth weight ${ }^{106-108}$, sudden infant death syndrome, altered corpus callosum, auditory defects, besides being related to future compromised fertility, type 2 diabetes, obesity, hypertension and respiratory dysfunction ${ }^{109,110}$. Nicotinic acetylcholine receptors regulate critical stages of brain development and nicotine neurotoxic effects on the developing brain have been widely demonstrated, including future hyperactivity, cognitive impairment, anxiety, mood and attention symptoms, sensitivity to stimulant drugs ${ }^{109,111-115}$. To date, e-cigarette impact on pregnant women and fetuses remains uncertain and further research should be established. A vast amount of studies carried out on animal models suggest pre- and postnatal alterations related with the exposure to both, nicotine and nicotine-free aerosols, including the down-regulation of genes implied in lung development ${ }^{116}$, an inverse relationship between plasma and urine cotinine level and body weight ${ }^{117}$, in addition to neurobehavioural and developmental disorders similar to those resulting from conventional cigarette exposure ${ }^{118}$.

\section{Cardiovascular effects}

Laboratory studies have pointed out that exposure to e-cigarette can induce platelet aggregation by upregulating expression of CD41 (GPIIb), CD42b, and CD62p (P-selectin) ${ }^{119}$. It also underlies oxidative stress elevation, impairment of antioxidant defenses (vitamin E reduction) and endothelium dysfunction/damage, evidenced by the detection of endothelial progenitor cells and microvescicles into the bloodstream ${ }^{120-122}$. All these alterations could play a role in cardiovascular risk increasement. It has been proven, indeed, that daily vaping represents an independent risk factor for myocardial infarction ${ }^{123}$, synergically amplified by exposure to nicotine, a parasympathomimetic alkaloid increasing heart rate and blood pressure ${ }^{124}$. Additionally, a 30 minutes vaping session seems inducing an unfavorable effect on aortic stiffness similar to traditional 
smoking ${ }^{125}$.

Neurological effects

Nicotine is widely recognized as a psychoactive substance ${ }^{126}$. Vapers experience craving, impaired capacity to stop and withdrawal symptoms during abstinence (e.g. irritability), which all suggest e-cigs potential of inducing nicotine dependence ${ }^{127,128}$. Similarly to other substance use disorders, adolescents are characteristically more vulnerable to addiction ${ }^{129}$.

Despite ENDS representing a tobacco cessation strategy, the risk of transition to conventional cigarettes in previously never smokers represents an emerging issue of critical relevance, especially in young people ${ }^{130-133}$. A recent meta-analysis showed that in a population of teens and young adults who have never smoked, odds of smoking initiation were 3 to 6 times higher in those who have ever used e-cigarettes ${ }^{134}$. Evidence suggest also that higher nicotine concentrations may heighten the likelihood of progression ${ }^{135}$. In this perspective, the renormalization of a smoking culture among teenagers threatens to subvert decades of anti-smoking efforts.

Structural and neurochemical changes in the central nervous system lie beneath the behavioral evolution that characterizes adolescence. Against this background, nicotine can affect its regular course, contributing to attention and cognitive deficits and exacerbating mood disorders ${ }^{136}$.

Furthermore, in such a critical phase of human development, nicotine exposure may prime the brain's reward system increasing pleasing effects of other substances of abuse ${ }^{137,138}$. As evidence of this, youngsters smoking e-cigarettes display a greater risk of co-occurring alcohol and/or marijuana use ${ }^{139}$.

Acute adverse effects

As regards e-cigarettes potential harmful effects, consideration should be given to acute injuries. A fair amount of reports to poison centers concern children incidentally exposed to e-cig liquids through ingestion $(70 \%)$, inhalation $(15 \%)$, ocular $(8.5 \%)$ and dermal contact $(6 \%)^{140}$. Nicotine poisoning can result in tachycardia, dizziness and even seizures ${ }^{141}$. Ingestion of $0,1 \mathrm{mg} / \mathrm{kg}$ of nicotine-containing fluid can be fatal to a child ${ }^{7}$. Acute exposure to e-cigarettes seems associated with a worse prognosis compared with that of conventional tobacco ${ }^{142}$. As electronic devices, batteries could also explode provoking severe burns ${ }^{143}$.

\section{COVID-19 and future perspectives}

It has been recently demonstrated that a nicotine-related overexpression of ACE-2 in bronchial epithelial cells is mediated by $\alpha 7$-subtype nicotinic receptors ${ }^{144}$. Within the framework of the ongoing COVID-19 pandemic, such a finding orients scientific interest towards the relationship between SARS-CoV2 and smoking or, more specifically, inhalation exposure to nicotine.

\section{Conclusions}

While traditional tobacco impairing effects have been widely demonstrated, vaping mid- and long-term complications remain unclear. Nonetheless, there is increasing evidence that e-cigarettes can no longer be considered as harmless devices. As a result of its cross-generational diffusion, vaping health implications have become an issue of pediatric interest, being children at greater risk of the still unknown chronic effects. According to a precautionary principle, e-cigarettes should be in any event considered unhealthy and consequently banned in this age group. In this perspective, governments should strengthen prevention strategies as well as restrictions and regulations on e-cigarettes marketing and advertisings. At the same time, teachers and pediatricians must play a crucial role in children and parents' education by raising their awareness about vaping harmful effects and dispelling widespread misperceptions. Given its ever-growing relevance as a worldwide health concern, further investigation is in our main interest.

\section{References}

1. Heiss C. Electronic cigarettes: Replacing one evil with another? Eur J Prev Cardiol 2019;26(11):12171218. 
2. Samet JM. Tobacco smoking. The leading cause of preventable disease worldwide. Thorac Surg Clin 2013.

3. Thirion-Romero I, Pérez-Padilla R, Zabert G, Barrientos-Gutierrez I. Respiratory impact of electronic cigarettes and low-risk tobacco. Rev Investig Clin 2019;71(1):17-27.

4. Gravely S, Fong GT, Cummings KM, Yan M, Quah ACK, Borland R, Yong HH, Hitchman SC, McNeill A, Hammond D, et al. Awareness, trial, and current use of electronic cigarettes in 10 countries: Findings from the ITC project. Int J Environ Res Public Health 2014.

5. Gorini G, Gallus S, Carreras G, Cortini B, Vannacci V, Charrier L, Cavallo F, Molinaro S, Galeone D, Spizzichino L, et al. A long way to go: 20-year trends from multiple surveillance systems show a still huge use of tobacco in minors in Italy. Eur J Public Health 2019.

6. Jenssen BP, Walley SC, Groner JA, Rahmandar M, Boykan R, Mih B, Marbin JN, Caldwell AL. Ecigarettes and similar devices. Pediatrics 2019.

7. Binns C, Lee MK, Low WY. Children and E-Cigarettes: A New Threat to Health. Asia-Pacific J Public Heal 2018;30(4):315-320.

8. Cullen KA, Ambrose BK, Gentzke AS, Apelberg BJ, Jamal A, King BA. Notes from the Field: Use of Electronic Cigarettes and Any Tobacco Product Among Middle and High School Students - United States, 2011-2018 . MMWR Morb Mortal Wkly Rep 2018.

9. Cullen KA, Gentzke AS, Sawdey MD, Chang JT, Anic GM, Wang TW, Creamer MLR, Jamal A, Ambrose BK, King BA. e-Cigarette Use among Youth in the United States, 2019. JAMA - J Am Med Assoc 2019.

10. Miech R, Johnston L, O’Malley PM, Bachman JG, Patrick ME. Trends in Adolescent Vaping, 2017-2019. N Engl J Med 2019.

11. ash. Use of e-cigarettes among young people in Great Britain. 2021 [accessed 2021 Mar 15]. https://ash.org.uk/wp-content/uploads/2021/02/YouthEcig2020.pdf

12. Gorini G, Gallus S, Carreras G, De Mei B, Masocco M, Faggiano F, Charrier L, Cavallo F, Spizzichino L, Galeone D, et al. Prevalence of tobacco smoking and electronic cigarette use among adolescents in Italy: Global Youth Tobacco Surveys (GYTS), 2010, 2014, 2018. Prev Med (Baltim) 2020;131(March).

13. Chun LF, Moazed F, Calfee CS, Matthay MA, Gotts JE. Pulmonary toxicity of e-cigarettes. Am J Physiol - Lung Cell Mol Physiol 2017.

14. Frieden TR, Jaffe HW, Richards CL, Iademarco MF. E-Cigarette Use Among Youth and Young Adults. A Report of the Surgeon General. Mmwr 2014.

15. Duke JC, Lee YO, Kim AE, Watson KA, Arnold KY, Nonnemaker JM, Porter L. Exposure to electronic cigarette television advertisements among youth and young adults. Pediatrics 2014.

16. Richardson A, Ganz O, Vallone D. Tobacco on the web: Surveillance and characterisation of online tobacco and e-cigarette advertising. Tob Control 2015.

17. Singh T, Agaku IT, Arrazola RA, Marynak KL, Neff LJ, Rolle IT, King BA. Exposure to advertisements and electronic cigarette use among us middle and high school students. Pediatrics 2016.

18. Ayers JW, Leas EC, Allem JP, Benton A, Dredze M, Althouse BM, Cruz TB, Unger JB. Why do people use electronic nicotine delivery systems (electronic cigarettes)? A content analysis of Twitter, 2012-2015. PLoS One 2017.

19. Allem JP, Dharmapuri L, Unger JB, Cruz TB. Characterizing JUUL-related posts on Twitter. Drug Alcohol Depend 2018. 
20. Tsai J, Walton K, Coleman BN, Sharapova SR, Johnson SE, Kennedy SM, Caraballo RS. Reasons for Electronic Cigarette Use Among Middle and High School Students - National Youth Tobacco Survey, United States, 2016. MMWR Morb Mortal Wkly Rep 2018.

21. Kong G, Morean ME, Cavallo DA, Camenga DR, Krishnan-Sarin S. Reasons for electronic cigarette experimentation and discontinuation among adolescents and young adults. Nicotine Tob Res 2015.

22. Bold KW, Kong G, Cavallo DA, Camenga DR, Krishnan-Sarin S. Reasons for trying e-cigarettes and risk of continued use. Pediatrics 2016.

23. Singh S, Windle SB, Filion KB, Thombs BD, O'Loughlin JL, Grad R, Eisenberg MJ. E-cigarettes and youth: Patterns of use, potential harms, and recommendations. Prev Med (Baltim) 2020.

24. Ambrose BK, Rostron BL, Johnson SE, Portnoy DB, Apelberg BJ, Kaufman AR, Choiniere CJ. Perceptions of the relative harm of cigarettes and E-cigarettes among U.S. youth. Am J Prev Med 2014.

25. Anand V, McGinty KL, O'Brien K, Guenthner G, Hahn E, Martin CA. E-cigarette use and beliefs among urban public high school students in North Carolina. J Adolesc Heal 2015.

26. Roditis M, Delucchi K, Cash D, Halpern-Felsher B. Adolescents' Perceptions of Health Risks, Social Risks, and Benefits Differ Across Tobacco Products. J Adolesc Heal 2016.

27. Pokhrel P, Little MA, Fagan P, Muranaka N, Herzog TA. Electronic cigarette use outcome expectancies among college students. Addict Behav 2014.

28. Gorukanti A, Delucchi K, Ling P, Fisher-Travis R, Halpern-Felsher B. Adolescents' attitudes towards e-cigarette ingredients, safety, addictive properties, social norms, and regulation. Prev Med (Baltim) 2017.

29. Henry DB, Kobus K, Schoeny ME. Accuracy and Bias in Adolescents' Perceptions of Friends' Substance Use. Psychol Addict Behav 2011.

30. Rimal RN, Real K. How behaviors are influenced by perceived norms a test of the theory of normative social behavior. Communic Res 2005.

31. Gaur S, Agnihotri R. Health Effects of Trace Metals in Electronic Cigarette Aerosols - a Systematic Review. Biol Trace Elem Res 2019.

32. Williams M, Ghai S, Talbot P. Disposable electronic cigarettes and electronic hookahs: Evaluation of performance. Nicotine Tob Res 2015.

33. Hua M, Omaiye EE, Luo W, McWhirter KJ, Pankow JF, Talbot P. Identification of Cytotoxic Flavor Chemicals in Top-Selling Electronic Cigarette Refill Fluids. Sci Rep 2019.

34. Grana R, Benowitz N, Glantz SA. Background paper on E-cigarettes (electronic nicotine delivery systems). Cent Tob Control Res Educ Univ California, San Fr a WHO Collab Cent Tob Control Prep World Heal Organ Tob Free Initiat 2013.

35. Hess CA, Olmedo P, Navas-Acien A, Goessler W, Cohen JE, Rule AM. E-cigarettes as a source of toxic and potentially carcinogenic metals. Environ Res 2017.

36. Olmedo P, Goessler W, Tanda S, Grau-Perez M, Jarmul S, Aherrera A, Chen R, Hilpert M, Cohen JE, Navas-Acien A, et al. Metal concentrations in e-cigarette liquid and aerosol samples: The contribution of metallic coils. Environ Health Perspect 2018.

37. Fox L. The Basics of Vaping - Types of E-Cig Atomizers and Vape Tanks. [accessed 2021 Mar 7]. https://ecigarettereviewed.com/types-of-atomizer/

38. Harrell PT, Eissenberg T. Automated dripping devices for vapers: RDTAs, bottomfeeders, squonk mods and dripboxes. Tob Control 2018. 
39. Keith S, Harper C, Williams R, Llados F, Coley C, Carlson-Lynch H. Toxicological Profile for DEET (N,N-Diethyl-Meta-Tolumide). 2017.

40. Williams M, Bozhilov KN, Talbot P. Analysis of the elements and metals in multiple generations of electronic cigarette atomizers. Environ Res 2019.

41. Williams M, Talbot P. Design features in multiple generations of electronic cigarette atomizers. Int J Environ Res Public Health 2019;16(16).

42. Omaiye EE, McWhirter KJ, Luo W, Pankow JF, Talbot P. High-Nicotine Electronic Cigarette Products: Toxicity of JUUL Fluids and Aerosols Correlates Strongly with Nicotine and Some Flavor Chemical Concentrations. Chem Res Toxicol 2019.

43. Kavuluru R, Han S, Hahn EJ. On the popularity of the USB flash drive-shaped electronic cigarette Juul. Tob Control 2019.

44. Barrington-Trimis JL, Leventhal AM. Adolescents' Use of "Pod Mod" E-Cigarettes - Urgent Concerns. N Engl J Med 2018.

45. Yingst JM, Lester C, Veldheer S, Allen SI, Du P, Foulds J. E-cigarette users commonly stealth vape in places where e-cigarette use is prohibited. Tob Control 2019.

46. Gotts JE, Jordt SE, McConnell R, Tarran R. What are the respiratory effects of e-cigarettes? BMJ 2019;366:1-16.

47. Talih S, Balhas Z, Eissenberg T, Salman R, Karaoghlanian N, Hellani A El, Baalbaki R, Saliba N, Shihadeh A. Effects of user puff topography, device voltage, and liquid nicotine concentration on electronic cigarette nicotine yield: Measurements and model predictions. Nicotine Tob Res 2015.

48. Uchiyama S, Ohta K, Inaba Y, Kunugita N. Determination of carbonyl compounds generated from the E-cigarette using coupled silica cartridges impregnated with hydroquinone and 2,4-dinitrophenylhydrazine, followed by high-performance liquid chromatography. Anal Sci 2013.

49. Talih S, Balhas Z, Salman R, Karaoghlanian N, Shihadeh A. "Direct dripping": A high-temperature, high- formaldehyde emission electronic cigarette use method. Nicotine Tob Res 2016.

50. Callahan-Lyon P. Electronic cigarettes: Human health effects. Tob Control 2014;23(SUPPL. 2).

51. Etter JF, Bullen C, Flouris AD, Laugesen M, Eissenberg T. Electronic nicotine delivery systems: A research agenda. Tob Control 2011.

52. Li Q, Zhan Y, Wang L, Leischow SJ, Zeng DD. Analysis of symptoms and their potential associations with e-liquids' components: A social media study. BMC Public Health 2016.

53. Phillips B, Titz B, Kogel U, Sharma D, Leroy P, Xiang Y, Vuillaume G, Lebrun S, Sciuscio D, Ho J, et al. Toxicity of the main electronic cigarette components, propylene glycol, glycerin, and nicotine, in SpragueDawley rats in a 90-day OECD inhalation study complemented by molecular endpoints. Food Chem Toxicol 2017.

54. Kosmider L, Sobczak A, Fik M, Knysak J, Zaciera M, Kurek J, Goniewicz ML. Carbonyl compounds in electronic cigarette vapors: Effects of nicotine solvent and battery output voltage. Nicotine Tob Res 2014.

55. Laino T, Tuma C, Moor P, Martin E, Stolz S, Curioni A. Mechanisms of propylene glycol and triacetin pyrolysis. J Phys Chem A 2012.

56. Lerner CA, Sundar IK, Yao H, Gerloff J, Ossip DJ, McIntosh S, Robinson R, Rahman I. Vapors produced by electronic cigarettes and E-juices with flavorings induce toxicity, oxidative stress, and inflammatory response in lung epithelial cells and in mouse lung. PLoS One 2015. 
57. Fernández E, Ballbè M, Sureda X, Fu M, Saltó E, Martínez-Sánchez JM. Particulate Matter from Electronic Cigarettes and Conventional Cigarettes: a Systematic Review and Observational Study. Curr Environ Heal reports 2015.

58. Wang G, Liu W, Song W. Toxicity assessment of electronic cigarettes. Inhal Toxicol 2019;31(7):259-273.

59. Environmental Protection Agency. Volatile Organic Compounds' Impact on Indoor Air Quality. Epa 2018.

60. Agency for Toxic Substances and Disease Registry (ATSDR). Public Health Statement: Polycyclic Aromatic Hydrocarbons (PAHs). AtsdrCdcGov 1995.

61. Pamies D, Vilanova E. Acrolein. In: Encyclopedia of Toxicology: Third Edition. 2014.

62. Reidel B, Radicioni G, Clapp PW, Ford AA, Abdelwahab S, Rebuli ME, Haridass P, Alexis NE, Jaspers I, Kesimer M. E-cigarette use causes a unique innate immune response in the lung, involving increased neutrophilic activation and altered mucin secretion. Am J Respir Crit Care Med 2018.

63. Breland A, Soule E, Lopez A, Ramôa C, El-Hellani A, Eissenberg T. Electronic cigarettes: what are they and what do they do? Ann N Y Acad Sci 2017.

64. Clapp PW, Jaspers I. Electronic Cigarettes: Their Constituents and Potential Links to Asthma. Curr Allergy Asthma Rep 2017.

65. Kosmider L, Sobczak A, Prokopowicz A, Kurek J, Zaciera M, Knysak J, Smith D, Goniewicz ML. Cherry-flavoured electronic cigarettes expose users to the inhalation irritant, Benzaldehyde. Thorax 2016.

66. Gerloff J, Sundar IK, Freter R, Sekera ER, Friedman AE, Robinson R, Pagano T, Rahman I. Inflammatory Response and Barrier Dysfunction by Different e-Cigarette Flavoring Chemicals Identified by Gas Chromatography-Mass Spectrometry in e-Liquids and e-Vapors on Human Lung Epithelial Cells and Fibroblasts. Appl Vitr Toxicol 2017.

67. Barrington-Trimis JL, Samet JM, McConnell R. Flavorings in electronic cigarettes: An unrecognized respiratory health hazard? JAMA - J Am Med Assoc 2014.

68. National Institute for Occupational Safety and Health. Flavorings- Related Lung Disease. [accessed 2021 Mar 8]. https://www.cdc.gov/niosh/topics/flavorings/exposure.html

69. Pepper JK, Ribisl KM, Brewer NT. Adolescents' interest in trying flavoured e-cigarettes. Tob Control 2016.

70. Morean ME, Kong G, Cavallo DA, Camenga DR, Krishnan-Sarin S. Nicotine concentration of e-cigarettes used by adolescents. Drug Alcohol Depend 2016.

71. Kim HJ, Shin HS. Determination of tobacco-specific nitrosamines in replacement liquids of electronic cigarettes by liquid chromatography-tandem mass spectrometry. J Chromatogr A 2013.

72. CDC. About Electronic Cigarettes. [accessed 2021 Apr 9]. https://www.cdc.gov/tobacco/basic_information/e-cigarettes/about-e-cigarettes.html

73. Schweitzer KS, Chen SX, Law S, Van Demark M, Poirier C, Justice MJ, Hubbard WC, Kim ES, Lai X, Wang M, et al. Endothelial disruptive proinflammatory effects of nicotine and e-cigarette vapor exposures. Am J Physiol - Lung Cell Mol Physiol 2015.

74. Ghosh A, Coakley RC, Mascenik T, Rowell TR, Davis ES, Rogers K, Webster MJ, Dang H, Herring LE, Sassano MF, et al. Chronic e-cigarette exposure alters the human bronchial epithelial proteome. Am J Respir Crit Care Med 2018.

75. Vardavas CI, Anagnostopoulos N, Kougias M, Evangelopoulou V, Connolly GN, Behrakis PK. Shortterm pulmonary effects of using an electronic cigarette: Impact on respiratory flow resistance, impedance, 
and exhaled nitric oxide. Chest 2012.

76. Meo SA, Ansary MA, Barayan FR, Almusallam AS, Almehaid AM, Alarifi NS, Alsohaibani TA, Zia I. Electronic Cigarettes: Impact on Lung Function and Fractional Exhaled Nitric Oxide Among Healthy Adults. Am J Mens Health 2019.

77. Marini S, Buonanno G, Stabile L, Ficco G. Short-term effects of electronic and tobacco cigarettes on exhaled nitric oxide. Toxicol Appl Pharmacol 2014.

78. McConnell R, Barrington-Trimis JL, Wang K, Urman R, Hong H, Unger J, Samet J, Leventhal A, Berhane K. Electronic cigarette use and respiratory symptoms in adolescents. Am J Respir Crit Care Med 2017.

79. Wang MP, Ho SY, Leung LT, Lam TH. Electronic Cigarette Use and Respiratory Symptoms in Chinese Adolescents in Hong Kong. JAMA Pediatr 2016.

80. Carwile JL, Fleisch AF, Young K, Ahrens KA. Electronic Cigarette Use in US Households with Children: The "new" Secondhand Smoke. JAMA Pediatr 2019.

81. Bayly JE, Bernat D, Porter L, Choi K. Secondhand Exposure to Aerosols From Electronic Nicotine Delivery Systems and Asthma Exacerbations Among Youth With Asthma. Chest 2019.

82. Cho JH, Paik SY. Association between electronic cigarette use and asthma among high school students in South Korea. PLoS One 2016.

83. Carson JL, Zhou L, Brighton L, Mills KH, Zhou H, Jaspers I, Hazucha M. Temporal structure/function variation in cultured differentiated human nasal epithelium associated with acute single exposure to tobacco smoke or E-cigarette vapor. Inhal Toxicol 2017.

84. Dicpinigaitis P V., Chang AL, Dicpinigaitis AJ, Negassa A. Effect of e-cigarette use on cough reflex sensitivity. Chest 2016.

85. Miyashita L, Suri R, Dearing E, Mudway I, Dove RE, Neill DR, Van Zyl-Smit R, Kadioglu A, Grigg J. E-cigarette vapour enhances pneumococcal adherence to airway epithelial cells. Eur Respir J 2018.

86. Hwang JH, Lyes M, Sladewski K, Enany S, McEachern E, Mathew DP, Das S, Moshensky A, Bapat S, Pride DT, et al. Electronic cigarette inhalation alters innate immunity and airway cytokines while increasing the virulence of colonizing bacteria. J Mol Med 2016.

87. Cherian S V., Kumar A, Estrada-Y-Martin RM. E-Cigarette or Vaping Product-Associated Lung Injury: A Review. Am J Med 2020;133(6):657-663.

88. Layden JE, Ghinai I, Pray I, Kimball A, Layer M, Tenforde MW, Navon L, Hoots B, Salvatore PP, Elderbrook M, et al. Pulmonary Illness Related to E-Cigarette Use in Illinois and Wisconsin - Final Report. N Engl J Med 2020.

89. Kowitt SD, Osman A, Meernik C, Zarkin GA, Ranney LM, Martin J, Heck C, Goldstein AO. Vaping cannabis among adolescents: Prevalence and associations with tobacco use from a cross-sectional study in the USA. BMJ Open 2019.

90. Blount BC, Karwowski MP, Shields PG, Morel-Espinosa M, Valentin-Blasini L, Gardner M, Braselton M, Brosius CR, Caron KT, Chambers D, et al. Vitamin E Acetate in Bronchoalveolar-Lavage Fluid Associated with EVALI. N Engl J Med 2020.

91. Kalininskiy A, Bach CT, Nacca NE, Ginsberg G, Marraffa J, Navarette KA, McGraw MD, Croft DP. E-cigarette, or vaping, product use associated lung injury (EVALI): case series and diagnostic approach. Lancet Respir Med 2019.

92. Triantafyllou GA, Tiberio PJ, Zou RH, Lamberty PE, Lynch MJ, Kreit JW, Gladwin MT, Morris A, Chiarchiaro J. Vaping-associated acute lung injury: A case series. Am J Respir Crit Care Med 2019. 
93. Henry TS, Kanne JP, Kligerman SJ. Imaging of Vaping-Associated Lung Disease. N Engl J Med 2019.

94. Mukhopadhyay S, Mehrad M, Dammert P, Arrossi A V., Sarda R, Brenner DS, Maldonado F, Choi H, Ghobrial M. Lung biopsy findings in severe pulmonary illness associated with E-Cigarette use (Vaping): A report of eight cases. Am J Clin Pathol 2020.

95. Blagev DP, Harris D, Dunn AC, Guidry DW, Grissom CK, Lanspa MJ. Clinical presentation, treatment, and short-term outcomes of lung injury associated with e-cigarettes or vaping: a prospective observational cohort study. Lancet 2019.

96. McCauley L, Markin C, Hosmer D. An unexpected consequence of electronic cigarette use. Chest 2012.

97. Thota D, Latham E. Case report of electronic cigarettes possibly associated with eosinophilic pneumonitis in a previously healthy active-duty sailor. J Emerg Med 2014.

98. Hureaux J, Drouet M, Urban T. A case report of subacute bronchial toxicity induced by an electronic cigarette. Thorax 2014.

99. Vannier S, Ronziere T, Ferre JC, Lassalle V, Verin M. Reversible cerebral vasoconstriction syndrome triggered by an electronic cigarette: Case report. Eur J Neurol 2015.

100. Drehmer JE, Nabi-Burza E, Walters BH, Ossip DJ, Levy DE, Rigotti NA, Klein JD, Winickoff JP. Parental smoking and E-Cigarette use in homes and cars. Pediatrics 2019;143(4).

101. Ballbè M, Martínez-Sánchez JM, Sureda X, Fu M, Pérez-Ortuño R, Pascual JA, Saltó E, Fernández E. Cigarettes vs. e-cigarettes: Passive exposure at home measured by means of airborne marker and biomarkers. Environ Res 2014.

102. Soule EK, Maloney SF, Spindle TR, Rudy AK, Hiler MM, Cobb CO. Electronic cigarette use and indoor air quality in a natural setting. Tob Control 2017.

103. Ruprecht AA, De Marco C, Pozzi P, Munarini E, Mazza R, Angellotti G, Turla F, Boffi R. Comparison between particulate matter and ultrafine particle emission by electronic and normal cigarettes in real-life conditions. Tumori 2014.

104. Whittington JR, Simmons PM, Phillips AM, Gammill SK, Cen R, Magann EF, Cardenas VM. The Use of Electronic Cigarettes in Pregnancy: A Review of the Literature. Obstet Gynecol Surv 2018.

105. Spector LG, Murphy SE, Wickham KM, Lindgren B, Joseph AM. Prenatal tobacco exposure and cotinine in newborn dried blood spots. Pediatrics 2014.

106. Gunnerbeck A, Bonamy AKE, Wikström AK, Granath F, Wickström R, Cnattingius S. Maternal snuff use and smoking and the risk of oral cleft malformations - A population-based cohort study. PLoS One 2014.

107. Dahlin S, Gunnerbeck A, Wikström AK, Cnattingius S, Edstedt Bonamy AK. Maternal tobacco use and extremely premature birth - a population-based cohort study. BJOG An Int J Obstet Gynaecol 2016.

108. Baba S, Wikström AK, Stephansson O, Cnattingius S. Changes in snuff and smoking habits in Swedish pregnant women and risk for small for gestational age births. BJOG An Int J Obstet Gynaecol 2013.

109. Bruin JE, Gerstein HC, Holloway AC. Long-term consequences of fetal and neonatal nicotine exposure: A critical review. Toxicol Sci 2010.

110. Dhalwani NN, Szatkowski L, Coleman T, Fiaschi L, Tata LJ. Nicotine replacement therapy in pregnancy and major congenital anomalies in offspring. Pediatrics 2015.

111. Goriounova NA, Mansvelder HD. Short- and long-term consequences of nicotine exposure during adolescence for prefrontal cortex neuronal network function. Cold Spring Harb Perspect Med 2012.

112. Dwyer JB, McQuown SC, Leslie FM. The dynamic effects of nicotine on the developing brain. Pharmacol Ther 2009. 
113. England LJ, Bunnell RE, Pechacek TF, Tong VT, McAfee TA. Nicotine and the Developing Human: A Neglected Element in the Electronic Cigarette Debate. Am J Prev Med 2015.

114. Schraufnagel DE. Electronic Cigarettes: Vulnerability of Youth. Pediatr Allergy, Immunol Pulmonol 2015.

115. Pauly JR, Slotkin TA. Maternal tobacco smoking, nicotine replacement and neurobehavioural development. Acta Paediatr Int J Paediatr 2008.

116. Noël A, Hansen S, Zaman A, Perveen Z, Pinkston R, Hossain E, Xiao R, Penn A. In utero exposures to electronic-cigarette aerosols impair the Wnt signaling during mouse lung development. Am J Physiol - Lung Cell Mol Physiol 2020.

117. S.A. M-M, M. H, A. A, A. L, A. M, J.M. C, E. N, J.D. K, J.P. W, P. B, et al. The effects of electronic cigarette emissions on systemic cotinine levels, weight and postnatal lung growth in neonatal mice. PLoS One 2015.

118. Lauterstein DE, Tijerina PB, Corbett K, Oksuz BA, Shen SS, Gordon T, Klein CB, Zelikoff JT. Frontal cortex transcriptome analysis of mice exposed to electronic cigarettes during early life stages. Int J Environ Res Public Health 2016.

119. Hom S, Chen L, Wang T, Ghebrehiwet B, Yin W, Rubenstein DA. Platelet activation, adhesion, inflammation, and aggregation potential are altered in the presence of electronic cigarette extracts of variable nicotine concentrations. Platelets 2016.

120. Antoniewicz L, Bosson JA, Kuhl J, Abdel-Halim SM, Kiessling A, Mobarrez F, Lundbäck M. Electronic cigarettes increase endothelial progenitor cells in the blood of healthy volunteers. Atherosclerosis 2016.

121. Carnevale R, Sciarretta S, Violi F, Nocella C, Loffredo L, Perri L, Peruzzi M, Marullo AGM, De Falco E, Chimenti I, et al. Acute Impact of Tobacco vs Electronic Cigarette Smoking on Oxidative Stress and Vascular Function. Chest 2016.

122. Staudt MR, Salit J, Kaner RJ, Hollmann C, Crystal RG. Altered lung biology of healthy never smokers following acute inhalation of E-cigarettes. Respir Res 2018.

123. Alzahrani T, Pena I, Temesgen N, Glantz SA. Association Between Electronic Cigarette Use and Myocardial Infarction. Am J Prev Med 2018.

124. Yan XS, D'Ruiz C. Effects of using electronic cigarettes on nicotine delivery and cardiovascular function in comparison with regular cigarettes. Regul Toxicol Pharmacol 2015.

125. Vlachopoulos C, Ioakeimidis N, Abdelrasoul M, Terentes-printzios D, Georgakopoulos C, Pietri P, Stefanadis C, Tousoulis D. Electronic Cigarette Stiffness and Blood Pressure in Young Smokers Treatment of Pure Aortic Regurgitation Using a Second-Generation. J Am Coll Cardiol 2016;67(23):2802-2803.

126. Murray JB. Nicotine as a psychoactive drug. J Psychol Interdiscip Appl 1991.

127. Foulds J, Veldheer S, Yingst J, Hrabovsky S, Wilson SJ, Nichols TT, Eissenberg T. Development of a questionnaire for assessing dependence on electronic cigarettes among a large sample of ex-smoking e-cigarette users. Nicotine Tob Res 2015.

128. Etter JF, Eissenberg T. Dependence levels in users of electronic cigarettes, nicotine gums and tobacco cigarettes. Drug Alcohol Depend 2015.

129. Pentz MA, Shin HS, Riggs N, Unger JB, Collison KL, Chou CP. Parent, peer, and executive function relationships to early adolescent e-cigarette use: A substance use pathway? Addict Behav 2015.

130. Spindle TR, Hiler MM, Cooke ME, Eissenberg T, Kendler KS, Dick DM. Electronic cigarette use and uptake of cigarette smoking: A longitudinal examination of U.S. college students. Addict Behav 2017. 
131. Bold KW, Kong G, Camenga DR, Simon P, Cavallo DA, Morean ME, Krishnan-Sarin S. Trajectories of E-cigarette and conventional cigarette use among youth. Pediatrics 2018.

132. Leventhal AM, Strong DR, Kirkpatrick MG, Unger JB, Sussman S, Riggs NR, Stone MD, Khoddam R, Samet JM, Audrain-McGovern J. Association of electronic cigarette use with initiation of combustible tobacco product smoking in early adolescence. JAMA - J Am Med Assoc 2015.

133. Primack BA, Soneji S, Stoolmiller M, Fine MJ, Sargent JD. Progression to traditional cigarette smoking after electronic cigarette use among us adolescents and young adults. JAMA Pediatr 2015.

134. Soneji S, Barrington-Trimis JL, Wills TA, Leventhal AM, Unger JB, Gibson LA, Yang JW, Primack BA, Andrews JA, Miech RA, et al. Association between initial use of e-cigarettes and subsequent cigarette smoking among adolescents and young adults a systematic review and meta-analysis. JAMA Pediatr 2017.

135. Goldenson NI, Leventhal AM, Stone MD, McConnell RS, Barrington-Trimis JL. Associations of electronic cigarette nicotine concentration with subsequent cigarette smoking and vaping levels in adolescents. JAMA Pediatr 2017.

136. Yuan M, Cross SJ, Loughlin SE, Leslie FM. Nicotine and the adolescent brain. J Physiol 2015.

137. Agrawal A, Madden PAF, Martin NG, Lynskey MT. Do early experiences with cannabis vary in cigarette smokers? Drug Alcohol Depend 2013.

138. Huang YY, Kandel DB, Kandel ER, Levine A. Nicotine primes the effect of cocaine on the induction of LTP in the amygdala. Neuropharmacology 2013.

139. Camenga DR, Kong G, Cavallo DA, Liss A, Hyland A, Delmerico J, Cummings KM, Krishnan-Sarin S. Alternate tobacco product and drug use among adolescents who use electronic cigarettes, cigarettes only, and never smokers. J Adolesc Heal 2014.

140. Collaco JM, McGrath-Morrow SA. Electronic Cigarettes: Exposure and Use Among Pediatric Populations. J Aerosol Med Pulm Drug Deliv 2018;31(2):71-77.

141. Govindarajan P, Spiller HA, Casavant MJ, Chounthirath T, Smith GA. E-Cigarette and liquid nicotine exposures among young children. Pediatrics 2018.

142. Kamboj A, Spiller HA, Casavant MJ, Chounthirath T, Smith GA. Pediatric exposure to e-cigarettes, nicotine, and tobacco products in the United States. Pediatrics 2016.

143. Patterson SB, Beckett AR, Lintner A, Leahey C, Greer A, Brevard SB, Simmons JD, Kahn SA. A Novel Classification System for Injuries after Electronic Cigarette Explosions. J Burn Care Res 2017.

144. Wang Q, Sundar IK, Li D, Lucas JH, Muthumalage T, McDonough SR, Rahman I. E-cigarette-induced pulmonary inflammation and dysregulated repair are mediated by $\mathrm{nAChR} \alpha 7$ receptor: Role of $\mathrm{nAChR} \alpha 7$ in SARS-CoV-2 Covid-19 ACE2 receptor regulation. Respir Res 2020;21(1):1-17. 